\title{
Informed Consent to Patients in Root Canal Treatment (Case Study: Melati Dental Clinic Jakarta, Indonesia)
}

\author{
Pudentiana Rr RE ${ }^{1}$, Tedi Purnama ${ }^{1}$, Syifa Yulia Lestari ${ }^{2}$, Yulianti ${ }^{3}$ \\ 1,2 Assistant Professor, ${ }^{3}$ Lecturer, Department of Dental Health, Health Polytechnic of Jakarta I, Indonesia, \\ ${ }^{4}$ Dental Nurse, Melati Dental Clinic Jakarta, Indonesia
}

\begin{abstract}
Teeth with necrosis require root canal treatment. Before taking any action, the treatment plan that will be carried out along with the risks must be explained clearly to the patient and his family, and then must get informed consent for the treatment plan. The purpose of this study was to the description of informed consent in patients with root canal treatment at the Melati Dental Clinic in Jakarta. Method: This research uses descriptive method with research sample using technique total sampling of 50 respondents. The data used are secondary data taken from the patient's medical record. Results: Respondents 33 people (66\%) provided complete informed consent and 17 people (34\%) did not give complete informed consent. Respondents doing root canal treatment caused by caries as many as 38 people $(76 \%)$ and respondent root canal treatment caused not because of caries as many as 12 people (24\%). Respondents provided complete informed consent in patients with root canal treatment because of caries by 27 people $(71 \%)$ and giving complete informed consent not because of caries by 6 people (50\%). Whereas giving informed consent was incomplete because of caries as many as 11 people (29\%) and incomplete informed consent was not due to caries as many as 6 people (50\%). Conclusion: Management of Informed Consent in Root Canal Treatment patients at Melati Dental Clinic in Jakarta has been carried out well.
\end{abstract}

Keywords: Informed Consent, Root Canal Treatment.

\section{Introduction}

Dental and oral health services are carried out to maintain and improve the degree of public health in the form of improving dental health, dental disease, dental disease treatment and restoration of dental health by the central government, regional governments or the community which are carried out in an integrated, integrated and sustainable manner. ${ }^{1}$

Dental health is an integral part of overall health that can affect quality of life. ${ }^{2}$ The most prominent dental

\section{Corresponding Author:}

\section{Tedi Purnama}

Department of Dental Health, Health Polytechnic of Jakarta I, Wijaya Kusuma Raya Street, No. 47, Jakarta, Indonesia

e-mail: tedypurnama23@yahoo.com health problems in Indonesia a problem of tooth loss due to dental caries. Dental caries is experienced by $90 \%$ of Indonesian people. ${ }^{3}$

The results of the Basic Health Research in 2018 reported that $92.2 \%$ of Indonesia's population aged 35 44 years experienced dental health problems; a DMF-T index of 6.9 means that the average number of tooth decay is 6 to 7 teeth per person. ${ }^{4}$

Dental caries is a process of demineralizing tooth hard tissue structures such as dentin and enamel. Dental caries or cavities is a dental and oral health problem that is often experienced by almost all people in Indonesia. ${ }^{5}$ According to Tarigan (2013) dental caries is a disease of dental tissue characterized by tissue damage, starting from the surface of the teeth extending towards the pulp. Dental caries can be experienced by anyone and can arise on one or more surfaces, and can extend to deeper parts of the teeth, for example from enamel to dentin or to the pulp. ${ }^{6}$ 
Untreated caries results in disruption of maximal dental function. Tooth decay can be preceded by pulp inflammation and if not treated can continue with pulp death or what is known as pulp necrosis. Teeth with necrosis require root canal treatment, which aims to clear the pulp chamber from infected pulp tissue, then form a root canal for obturation to form an apical seal. ${ }^{7}$

Root canal treatment often requires the removal of enough hard tissue so that it leaves little hard tissue and cannot support the restoration properly because it is easy to crack or fracture. Root canal treatment is done in several visits. ${ }^{7}$ Before taking any action, the plan of treatment that will be carried out along with the risks must be explained clearly to the patient and his family, and then must get approval for the action plan. ${ }^{8}$

Informed consent is the consent obtained by the doctor given by the patient or family on the basis of an explanation of the medical action in the form of examination, treatment or any medical action that will be carried out on the patient. ${ }^{9}$ Approval of medical treatment can be stated verbally and in writing. Verbal consent where the patient states the patient's consent verbally and does not sign in written form, whereas written consent is needed in the case of broad interventions involving risks where anesthesia or sedation is used as a restorative, invasive or surgical procedure, administration of high risk drugs. ${ }^{10}$

Dentists in providing services to patients need to be vigilant, given the various cases that occur due to carelessness which ultimately lead to legal problems, including due to the incompleteness of one of the means in dentistry services to the public, namely the completeness of medical action approval letters on medical services to patients. ${ }^{11}$ Considering the risk of the treatment, in anticipation of a continuing dispute, it is better that the consent given by the patient to the dentist who will treat it be given in writing. ${ }^{8}$ Research Herwanda et al (2016) using a questionnaire on young gig doctors at Hospitals Teeth and Mouth Unsyiah, showed that subjects who used informed consent with good criteria were 246 people $(95.0 \%)$, moderate criteria were 12 people $(4.6 \%)$, and bad criteria of 1 person $(0.4 \%) .{ }^{10}$

Melati Dental Clinic is a private dental clinic in Central Jakarta that provides general and specialist dentistry services. The 2019 dental clinic report shows that there are three dental diseases with the highest number, namely pulp necrose, dental caries and pulpitis. This shows that root canal treatment is often done as a treatment for pulp necrose.

Based on the above background the authors are interested in conducting research under the title "Informed Consent in Root Canal Treatment patients in Melati Dental Clinic Jakarta"

\section{Method}

The research design used is descriptive research, is a method of research conducted with the main objective to make a picture or description of a situation objectively. ${ }^{12}$ This study was intended to look at the description of giving informed consent to root canal treatment patients at the Melati Dental Clinic in Jakarta. The population in this study were all medical records Jakarta Melati Dental Clinic patients who performed root canal treatment in January to March 2020 amounting to 50 patients. The sampling technique uses total sampling i.e. the entire population is sampled, so the sample this study as many as 50 patients. This study uses secondary data taken from the medical records of elderly people who have performed dental care in the period of January to March 2020, then recorded using the recapitulation sheet specified by the researchers. This research was processed and analyzed in an excel program and presented in the form of a frequency distribution.

\section{Result}

Table 1. Frequency distribution providing informed consent

\begin{tabular}{|c|l|c|c|}
\hline No. & $\begin{array}{l}\text { Complete Informed } \\
\text { Consent }\end{array}$ & Frequency & Percentage (\%) \\
\hline 1 & Yes & 33 & 66 \\
\hline 2 & Not & 17 & 34 \\
\hline \multicolumn{2}{|c|}{ Total } & $\mathbf{5 0}$ & $\mathbf{1 0 0}$ \\
\hline
\end{tabular}

Table 1 to show that respondent 33 people $(66 \%)$ received complete consent in root canal treatment and 17 people (34\%) received incomplete informed consent 
Table 2. Frequency distribution causes of root canal treatment

\begin{tabular}{|c|l|c|c|}
\hline No. & Root canal treatment & Frequency & Percentage (\%) \\
\hline 1 & $\begin{array}{l}\text { Root canal treatment } \\
\text { because of caries }\end{array}$ & 38 & 76 \\
\hline 2 & $\begin{array}{l}\text { Root canal treatment } \\
\text { not because of caries }\end{array}$ & 12 & 24 \\
\hline \multicolumn{2}{|c|}{ Total } & $\mathbf{5 0}$ & $\mathbf{1 0 0}$ \\
\hline
\end{tabular}

Table 2 shows that respondents treated root canals because of caries by 38 people $(76 \%)$ and treated root canals not because of caries by 12 people (24\%).

Table 3. Frequency distribution of complete informed consent for patients with root canal treatment

\begin{tabular}{|l|c|c|c|c|}
\hline \multirow{2}{*}{$\begin{array}{l}\text { Complete } \\
\text { Informed } \\
\text { Consent }\end{array}$} & \multicolumn{4}{|c|}{ Root canal treatment } \\
\cline { 2 - 5 } & \multicolumn{2}{|c|}{ Because of caries } & \multicolumn{2}{c|}{ Not because of caries } \\
\cline { 2 - 5 } & $\mathbf{n}$ & $\mathbf{\%}$ & $\mathbf{n}$ & $\%$ \\
\hline Yes & 27 & 71 & 6 & 50 \\
\hline Not & 11 & 29 & 6 & 50 \\
\hline Total & $\mathbf{3 8}$ & $\mathbf{1 0 0}$ & $\mathbf{1 2}$ & $\mathbf{1 0 0}$ \\
\hline
\end{tabular}

Based on table 3, shows that respondents provided complete informed consent for root canal treatment because of caries by 27 people (71\%) while giving complete informed consent for root canal treatment not for caries by 6 people $(50 \%)$. Respondents provided incomplete informed consent for root canal treatment because of caries by 11 people (29\%) while incomplete informed consent for root canal treatment was caused not by caries as many as 6 people $(50 \%)$.

\section{Discussion}

The results of the study gave informed consent obtained by respondents given complete informed consent on root canal treatment as many as 33 people (66\%) and incomplete informed consent as many as 17 people (34\%). This is in accordance with research Herwanda et al (2016)showed that research subjects using informed consent were $95.0 \%$. So it can be interpreted that previous studies have compliance giving informed consent that is better than the results of research conducted by researchers. This causes the doctor to not comply in giving informed consent because doctors' knowledge about the legal consequences of informed consent is also lacking. Lack of doctor's knowledge regarding the legal consequences of informed consent can lead to a lack of physician compliance in carrying out informed consent to patients. ${ }^{13}$ Strengthened statement Oktarina (2010), every medical action requires informed consent. ${ }^{9}$

Based on the explanation of the Regulation of the Minister of Health of the Republic of Indonesia No. 290/ MENKES/PER/III/2008 in Elisa et al 2016, informed consent is a one-sided statement of a patient or the legal one representing it in the form of approval of a medical or dental action plan submitted by a doctor or dentist, after receiving sufficient information to be able to making approval or rejection. ${ }^{14}$ In this case, the doctor who is obliged to provide information is the doctor who knows the patient's condition and matters relating to the medical actions to be taken, including the dentist at the Melati Dental Clinic in performing root canal treatment.

Root canal treatment often requires a large amount of hard tissue removal that leaves little hard tissue and cannot support the restoration properly because it is easy to crack or fracture so that it can be done with several visits. ${ }^{7}$ Also reinforced statements Budi (2013) to anticipate the occurrence of ongoing disputes, the consent of the patient to the dentist who will treat him should be given in writing. ${ }^{8}$

Results research overview of root canal treatment obtained by respondents 38 people $(76 \%)$ did root canal treatment because of caries and 12 people (24\%) did root canal treatment. This study shows the greater treatment of root canals caused by caries. This is in accordance with research Setyaningsih (2015) that indicated that the treatment of root canal treatment of patients in Hospitals Teeth and Mouth UNEJ was 36\% and the main cause was caries. ${ }^{15}$ Untreated caries results in disruption of maximal dental function. Tooth decay can be preceded by pulp inflammation and if not treated can continue with pulp death/necrosis. Teeth with necrosis require root canal treatment. Besides the causes of root canal treatment is not due to caries which is caused by other causes for example: trauma, chronic tooth abrasion and chronic periodontitis so that retroinfection occurs. ${ }^{7}$

The results showed that giving informed consent to root canal treatment patients because caries had been done well, although informed consent was still found. That is due to several things that occur including, there is no policy at Melati Dental Clinic in Jakarta in the use of informed consent so that the standard operating procedures for dentists and dental nurses give informed 
consent to patients before root canal treatment is not carried out properly, especially if the patient's condition so much that doctors and dental nurses forget to give informed consent. In addition there are usually also a number of patient requests that want to be done quickly because their teeth are sick and some who want to hurry home so that informed consent is incomplete.

\section{Conclusion}

Management informed consent on root canal treatment patients at the Melati Dental Clinic in Jakarta has been implemented well.

Source Funding: This study was done by selffunding from the authors.

Conflict of Interest: The authors declare that they have no conflict interests.

Ethical Clearance: The ethical clearance taken from Ethical Committee of Health Research, Health Polytechnic of JakartaI.

\section{Reference}

1 Ministry of Health. Guidelines for Basic Package for Dental and Oral Health Services in Community Health Centers. Jakarta Directorate General of Health Efforts the Ministry of Health Republic of Indonesia. 2012.

2 Purnama T, Rasipin R, Ngatemi. Tedi's Behavior Change Model to Improving Brushing Teeth Behavior Parents. J Appl Health Managemant Technology. 2020; 2 (1): 1-12.

3 Notohartojo IT, Suratri MAL, Riyadina W, Nainggolan O. Dental Caries Value of Industrial Zone Employees in Pulo Gadung Jakarta. Research Mediaian and Health Development. 2011; 21 (4).

4 Ministry of Health. Main Results of Basic Health Research in 2018. Ministry of HealthRepublic of Indonesia. 2018; 1-100.

5 Sosiawan A, Heroesoebekti R, Hapsoro A, Santosa LM. Description of Severity of Dental Caries in Women Age 36-45 Years Claket Hamlet Claket Village Pacet District Mojokerto Regency in April
2016. Dental Public Health Journal. 2015; 6 (2): $1-12$.

6 Tarigan R. Dental caries. Jakarta EGC. 2013.

7 Triharsa S, Mulyawati E. One-Visit Root Canal Treatment in Necrotic Pulps Accompanied by Crown Restoration of a Metal Fusion Porcelain Jacket with Fiber Reinforced Composite Stakes (Case of Maxillary Right Central Incisor Tooth). MajIndonesian Dental Medical Center. 2013: 20 (1): 71-7.

8 Budi AT, Jahja M. Application for Intracorona Dental Whitening Care. Journal of Nursing. 2018; $6(1): 42-4$.

9 Oktarina O. Informed Consent Policy in Dental Services in Indonesia Dental Care Informed Consent Policy in Indonesia. Jurnal Management of Health Services. 2010; 13 (01).

10 Herwanda H, Rahmayani L, Fadhilla S. Description of the Use of Informed Consent by the Young Dentist at RSM Unsyiah. Cakradonya Dent J. 2016; $8(2)$.

11 Juliawati M. The importance of an informed consent for a doctor's practice tooth. J PDGI. 2014; 63 (2): 46-53.

12 Notoatmodjo S. Health research methodology. Jakarta: Rineka Cipta; 2010.

13 Fikriya K, Sriatmi A, Jati SP. Analysis of Approval of Medical Action (Informed Consent) in the Framework of Hospital Accreditation Preparation in the Central Surgical Installation of Semarang City Hospital. Journal of Public Health. 2016; 4 (1): 44-54.

14 Elisa F, Busro A, Suharto R. Informed Consent Legal Study on Therapeutic Agreements between Doctors and Underage Patients Based on Minister of Health Regulation No. 290/Minister of Health/ Per/III/2008 Regarding the Approval of Medical Measures. Diponegoro Law J. 2016; 5 (1): 11.

15 Setyaningsih LS. Prevalence of Indications for Endodontic Care in Patients Visiting the 2015 UNEJ RSGM. Jember State University. 2015. 